\title{
Communication and cooperation in international insolvency: on best practices for insolvency office holders and cross-border communication between courts
}

\author{
Dr. Bernard Santen 1
}

Published online: 25 August 2015

(C) The Author(s) 2015. This article is published with open access at Springerlink.com

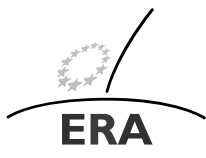

EUROPÄISCHE RECHTSAKADEMIE ACADEMY OF EUROPEAN LAW ACADEMIE DE DROIT EUROPEEN ACCADEMIA DI DIRITTO EUROPEO TRIER - TREVES - TREVIRI

\begin{abstract}
Communication, coordination and cooperation are key concepts in international insolvency law. This paper studies their place, meaning, development and application in present and coming European law. The focus lies on an introduction to three sets of soft law, recently developed to enable smoother communication, coordination and cooperation in practice with the objective to improve the effectivity and efficiency in international insolvency proceedings.
\end{abstract}

Keywords International insolvency $\cdot$ Cross-border insolvency $\cdot$ Communication · Coordination · Cooperation

\section{Introduction}

Over the past 20 years, communication, coordination and cooperation have become key concepts in international insolvency law. ${ }^{1}$ This paper surveys the present and coming position of these concepts in European Union hard law and soft law. It starts with a discussion in Sect. 2 on the "communication", "coordination" and "cooperation" concepts in the European Insolvency Regulation (EIR). ${ }^{2}$ Section 3 subse-

\footnotetext{
${ }^{1}$ See for example the 1995 European Convention on insolvency proceedings and the 1996 Virgós/Schmit report (L6500/96). For a complete survey, see Wessels [4].

${ }^{2}$ Council Regulation (EC) No. 1346/2000 of 29 May 2000 as subsequently updated until the moment of writing of this paper.
}

This article is based on a presentation given at the ERA conference "Cross-border insolvency proceedings" on 19-20 March 2015 which was organised in cooperation with INSOL Europe Academic Forum.

B. Santen, senior researcher

b.p.a.santen@law.leidenuniv.nl

1 Leiden Law School, Leiden, The Netherlands 
quently discusses the use of these concepts in the Regulation of the European Parliament and of the Council on insolvency proceedings (EIR Recast). ${ }^{3}$ As Sect. 4 will show, soft law seems the most appropriate means to operationalise the communication, coordination and cooperation-concepts in practice. This section discusses three sets of soft law which Leiden Law School prepared during 2013-2014, i.e. the draft INSOL Europe 2014 Statement of Principles and Guidelines for IOHs in Europe, the EU Cross-Border Insolvency Court-to-Court Cooperation Principles and the connected EU Cross-Border Insolvency Court-to-Court Communication Guidelines.

\section{Communication, coordination and cooperation in the EIR}

The EIR mentions communication, coordination and cooperation (further on indicated as: the three C-s concept) as one of the means to achieve the objective of the EIR, formulated in Recital 2 as "cross-border insolvency proceedings should operate efficiently and effectively". This is not a hollow phrase. When e.g. KPN-Qwest NV became insolvent in 2002, its European data-stock ring-network was sold piecemeal instead of under a central direction, which could have maintained the European ring and concluded in a much better central deal. Implementing the three $\mathrm{C}$-s concept would avoid many of the pointless quarrels between insolvency office holders $^{4}$ (IOHs) and long lasting discussions before courts, often costing creditors huge amounts of money. In short, the three C-s concept was implemented in order to improve the recovery rates.

The EIR introduced these "three C-s concepts" moderately. As Table 1 shows, "communication" is mentioned only four times, all of these in the text; "coordination" four times only in the recitals; and "cooperation" twice in the recitals and twice in the text.

The main presence of cooperation and communication is found in Article $31 \mathrm{EIR}$ ("Duty to cooperate and communicate information"). According to Article 31(1), the $\mathrm{IOH}$ in the main procedure and the $\mathrm{IOH}$ in the secondary procedure are duty bound to communicate information to each other which may be relevant to the other proceedings. This regards, as the text states, in particular the progress made in lodging and verifying claims and all measures aimed at terminating the proceedings. Article 31(2) EIR provides for a duty of cooperation between the main and the secondary IOH. Finally, Article 31(3) EIR requires a secondary IOH to give to the main IOH an early opportunity of submitting proposals on the liquidation or use of the assets in the secondary proceedings.

\footnotetext{
${ }^{3}$ As mentioned in: Position (EU) No. 7/2015 of the Council at First Reading with a view to the adoption of a Regulation of the European Parliament and of the Council on insolvency proceedings (recast), 2012/0360 (COD), adopted by the Council on 12 March 2015, (2015/C 141/01); as approved by the European Parliament legislative resolution of 20 May 2015; and as published as Regulation (EU) 2015/848 in OJ L 141/19 of 5 June 2015.

${ }^{4}$ The abbreviation "IOH", coined by the EBRD in their 2007 report: Office Holders Principles (2007), is used throughout this paper to indicate the liquidators mentioned in Annex C of the EIR and the insolvency practitioners of Annex B of the EIR Recast.
} 
Table 1 Survey of presence of communication, coordination and cooperation in the $\mathrm{EIR}^{5}$

\begin{tabular}{lll}
\hline & EIR No. 1346/2000 & \\
\cline { 2 - 3 } & Recital & Text \\
\hline Communication & - & 4 \\
& & (Article 31)
\end{tabular}

Coordination

4

(Recital 3, 12, 20, 21)

Cooperation

$2^{6}$

2

(Recitals 2, 20)

While communication apparently implies sharing of information as the text indicates, ${ }^{7}$ neither the recitals nor the articles provide insight into the application of "cooperation" or "coordination". Moreover it is remarkable that whilst "coordination" is found four times in the Recitals, it is found nowhere in the text. Apparently, according to the European legislator "coordination" implies either communication (and/) or cooperation. The question arises whether coordination and cooperation may be (largely) identical concepts. According to the Virgós/Schmit report, ${ }^{8}$ "the liquidators have a duty to act in concert with a view to the development of proceedings and their coordination, and to facilitate their respective work." In their view cooperation comes down to "act in concert". The on-line Oxford dictionaries give for coordinate: "Negotiate with others in order to work together effectively". And for cooperate: "Work jointly towards the same end". Since "act in concert" and "jointly working" imply a further stage of accommodation than "negotiation in order to work together" and "effectively" in the coordination description leaves open the presence of several aims instead of "the same end" in the cooperation description, the conclusion must be that:

\footnotetext{
${ }^{5}$ Or related verbs.
}

${ }^{6}$ Found in Recital 2, referring to "judicial cooperation" as meant in Article 65 of the former Treaty. Recital 20 is elaborated in Article 31 EIR.

${ }^{7}$ The 1996 Virgós/Schmit report refers to "communication" in Nos. 230-231. No. 230 states: "The exchange of information between the liquidators concerns in particular:

- the assets

- the actions planned or under way in order to recover assets; actions to obtain payment or actions for set aside

- possibilities for liquidating assets

- claims lodged

- verification of claims and disputes concerning them

- the ranking of creditors

- planned reorganisation measures

- proposed compositions

- plans for the allocation of dividends

- the progress of operations in the proceedings"

No. 231 adds that the duty to communicate "may be limited by national legislation on data exchange, e.g. by legislation relating to the protection of computerised personal data".

${ }^{8}$ No. 232. 
(1) "cooperation" is the farthest stage of tuning between IOHs in proceedings;

(2) "coordination" is the stage where IOHs negotiate in order to work together effectively; and

(3) "communication" comes down to sharing information with each other which may be relevant to the other proceedings.

In short, it seems that in the present text of the EIR, the legislator draws the relatively far reaching "cooperation-card" albeit only between IOHs. As the next section of this paper shows, the EIR Recast leans heavily on coordination as well.

\section{Communication, coordination and cooperation in the EIR Recast}

Contrary to the EIR, the EIR Recast mentions the "three C-s concepts" in abundancy. Already eight Articles show "cooperation and communication" in their headings, and there are five with "cooperation" in their heading, but only as in "group coordination".

Table 2 gives a breakdown of the presence of the "three C-s concepts" in the EIR Recast.

The EU apparently considers these "three C-s concepts" even more important today. Instead of 12 referrals to the concepts, the EIR Recast shows 226 referrals. Essentially, the present Recital 20 will be replaced by three new ones, 48, 49 and 50,

Table 2 Survey of presence of communication, coordination and cooperation in the EIR and the EIR recast

\begin{tabular}{|c|c|c|c|c|}
\hline & \multicolumn{2}{|c|}{ EIR No. $1346 / 2000$} & \multicolumn{2}{|l|}{ EIR Recast } \\
\hline & Recital & Text & Recital & Text \\
\hline Communication & - & $\begin{array}{l}4 \\
\text { (Article 31) }\end{array}$ & $\begin{array}{l}5 \\
\text { (Recital 48, 52, 59, 61, } \\
62 \text { ) }\end{array}$ & $\begin{array}{l}33^{9} \\
\text { (Article 25, 36, 41-44, } \\
53,56-59 ; 73,74,79 \text { ) }\end{array}$ \\
\hline Coordination & $\begin{array}{l}4 \\
(\text { Recital 3, 12, } \\
20,21)\end{array}$ & - & $\begin{array}{l}38^{10} \\
\text { (Recitals 4, 6, 23, 50, } \\
54-63 \text { ) }\end{array}$ & $\begin{array}{l}96^{11} \\
\text { (Articles 41-43; 56, 57, } \\
60-74 ; 77,99)\end{array}$ \\
\hline Cooperation & $\begin{array}{l}2^{12} \\
\text { (Recitals 2, 20) }\end{array}$ & $\begin{array}{l}2 \\
\text { (Article 31) }\end{array}$ & $\begin{array}{l}17^{13} \\
\text { (Recitals 3, 48, 49, 50, } \\
52,61,62)\end{array}$ & $\begin{array}{l}37^{14} \\
\text { (Articles 41-44; 56-59; } \\
74 \text { and } 85 \text { ) }\end{array}$ \\
\hline
\end{tabular}

\footnotetext{
${ }^{9}$ In Article 79, "communication" refers to communication to the European Commission.

${ }^{10}$ In Recital 4, "coordination" refers to "a need for a Union Act". Figures including "coordinator": 6x in Recitals, 39x in Articles.

${ }^{11}$ In Article 90, "coordination" is used in the review clause.

${ }^{12}$ In Recital 2, "cooperation" refers to Article 65 of the former Treaty establishing the European Community.

${ }^{13}$ In Recital 3, "cooperation" refers to Article 81 of the Treaty on the Functioning of the European Union.

${ }^{14}$ In Article 85 "cooperation" refers to Treaties having "Cooperation" in their name.
} 
and the current Article 31 by the new Articles 41, 42 and 43. Moreover, the EIR Recast adds Chapter V Insolvency Proceedings of Members of a Group of Companies, which Sect. 1 begins with cooperation and communication, and proceeds with coordination in Sect. 2.

A short glance at the Articles 41, 42 and 43 EIR Recast shows that Article 41(1) requires IOHs of the main and the secondary proceedings to "cooperate with each other to the extent such cooperation is not incompatible with the rules applicable to the respective proceedings. Such cooperation may take any form, including the conclusion of agreements or protocols".

This goes beyond the present Article 31 EIR, since being duty bound to communicate (para. 1) and to cooperate (para. 2) as it is now, seems more restricted than cooperation to the extent of incompatibility with the law. ${ }^{15}$ Article 41 EIR Recast requires ("shall") IOHs specifically (a) to communicate as soon as possible to each other any information which may be relevant to the other proceedings; ${ }^{16}$ (b) to explore the possibility of restructuring the debtor; ${ }^{17}$ and (c) to coordinate the administration of the realisation or use of the debtor's assets and affairs. ${ }^{18}$ This specification goes beyond the present Article 31(1) e.g. on restructuring and coordination.

In order to facilitate coordination of insolvency proceedings Article 42 EIR Recast requires "a court before which a request to open insolvency proceedings is pending, or which has opened such proceedings, (to) cooperate with any other court before which a request to open insolvency proceedings is pending, or which has opened such proceedings, to the extent that such cooperation is not incompatible with the rules applicable to each of the proceedings". According to Article 42(3) EIR Recast cooperation may, in particular, concern: (a) coordination in the appointment of the IOH; (b) communication of information by any means considered appropriate by the court; (c) coordination of the administration and supervision of the debtor's assets and affairs; (d) coordination of the conduct of hearings; (e) coordination in the approval of protocols, where necessary.

Finally, Article 43 EIR Recast requires IOHs to communicate and cooperate with (in short) all courts related to the insolvency proceedings to the extent that such cooperation is not incompatible with the law.

Already these Articles form a huge extension of the present obligation formulated in Article 31. The new Chapter V "Insolvency Proceedings of Members of a Group of Companies" adds to this two extensive and detailed sections applicable where insolvency proceedings relate to two or more members of a group of companies. The first section, on cooperation and communication in general, requires in Article 56 EIR Recast ("shall") an IOH appointed in proceedings concerning a member of the group to

\footnotetext{
${ }^{15}$ Although Article 41(1) EIR Recast refers to "the rules applicable to the respective proceedings" it should be interpreted in the author's view as "the law".

${ }^{16}$ The section continues: "in particular any progress made in lodging and verifying claims and all measures aimed at rescuing or restructuring the debtor, or at terminating the proceedings, provided appropriate arrangements are made to protect confidential information".

${ }^{17}$ The section continues: "and, where such a possibility exists, coordinate the elaboration and implementation of a restructuring plan".

${ }^{18}$ The section continues: "the insolvency practitioner in the secondary insolvency proceedings shall give the insolvency practitioner in the main insolvency proceedings an early opportunity to submit proposals on the realisation or use of the assets in the secondary insolvency proceedings".
} 
cooperate with any $\mathrm{IOH}$ appointed in proceedings concerning another member of the same group to the extent that such cooperation is appropriate to facilitate the effective administration of those proceedings, is not incompatible with the rules applicable to such proceedings and does not entail any conflict of interest. That cooperation may take any form, including the conclusion of agreements or protocols. It continues in Article 56(2): "In implementing the cooperation set out in paragraph 1, IOHs shall (a) as soon as possible communicate to each other any information which may be relevant to the other proceedings, provided appropriate arrangements are made to protect confidential information; (b) consider whether possibilities exist for coordinating the administration and supervision of the affairs of the group members which are subject to insolvency proceedings, and if so, coordinate such administration and supervision; (c) consider whether possibilities exist for restructuring group members which are subject to insolvency proceedings and, if so, coordinate with regard to the proposal and negotiation of a coordinated restructuring plan". Article 57 EIR Recast provides for a similar requirement ("shall") concerning cooperation between courts, including the same list of areas as mentioned in Article 42(3) EIR. And Article 58 EIR Recast (a) requires an $\mathrm{IOH}$ to cooperate and communicate with any court before which a request for the opening of proceedings in respect of another member of the same group of companies is pending or which has opened such proceedings; and (b) allows an $\mathrm{IOH}$ to request information from that court concerning the proceedings regarding the other member of the group or request assistance concerning the proceedings in which he has been appointed; to the extent that such cooperation and communication are appropriate to facilitate the effective administration. Essentially, these articles are similar to those in the general part of the EIR Recast (Articles 41-43). Section 2 of Chapter V provides for a very detailed procedure of coordination in these group proceedings. ${ }^{19}$ A discussion of this section is found elsewhere in this book.

Since the coordination and cooperation in "group of companies proceedings" is very well arranged for, the question arises how the European legislator envisages to operationalise the "three C-s concept" in situations of "main/secondary proceedings". This is the subject of the next section.

\section{Operationalisation of the "three C-s concept" in main and secondary proceedings}

Contrary to the Chapter V regulation, there is no regulation at all in the articles of the EIR Recast on the operationalisation of the "three C-s concept" in the case of main and secondary proceedings. However, the Recitals show a way out.

When cooperating, Recital 48 reads in the fifth sentence, IOHs and courts should take into account best practices for cooperation in cross-border insolvency cases, as set out in principles and guidelines on communication and cooperation adopted by European and international organisations active in the area of insolvency law, and in particular the relevant guidelines prepared by the United Nations Commission

\footnotetext{
${ }^{19}$ Interestingly, an opt-out for each of the proceedings is foreseen in the law, Article 65(1) EIR Recast.
} 
on International Trade Law (UNCITRAL). ${ }^{20}$ In light of such cooperation, Recital 49 continues, insolvency practitioners and courts should be able to enter into agreements and protocols for the purpose of facilitating cross-border cooperation of multiple insolvency proceedings in different Member States concerning the same debtor or members of the same group of companies. ${ }^{21}$

As so often, this clarification gives rise to new questions. What are best practices, principles and guidelines? What is adoption? Which organisations are active in insolvency law? And what are agreements and protocols? Of these questions, only the meaning of best practices, principles and guidelines will be dealt with in this paper. ${ }^{22}$

According to the text of the recital, best practices are found in principles and guidelines. What are these? In a study for INSOL Europe, ${ }^{23}$ TRI-Leiden defined "Principles" as general standards (Kaplow, ${ }^{24}$ 1992; Davies, ${ }^{25}$ 2010) of behaviour, to be made specific in a specific situation by the $\mathrm{IOH}$ himself. ${ }^{26}$ A Guideline is defined in that report in accordance with the online Merriam-Webster dictionary as "a rule or instruction that shows or tells how something should be done". ${ }^{27}$ A best practice then, could be described as either a general standard or a rule or instruction that ought to be followed save an acceptable explanation to the contrary ("comply or explain").

Over the past two years Leiden Law School (LLS) has designed two sets of Principles and Guidelines to be applied in accordance with (now) Recital 48 EIR Recast. This section will subsequently discuss the rules for IOHs and courts that LLS designed.

\subsection{The Draft Statement of Principles and Guidelines for IOHs}

Immediately after the publication of the EC evaluation report of the EIR, ${ }^{28}$ INSOL Europe took the initiative to assign a project to LLS to formulate Principles and Guidelines for IOHs in Europe. ${ }^{29}$ Governed by an Academic Committee and a Review and Advisory Group, LLS drafted three reports. Report I contains a framework

\footnotetext{
${ }^{20}$ The Recital starts as follows: Main insolvency proceedings and secondary insolvency proceedings can contribute to the efficient administration of the debtor's insolvency estate or to the effective realisation of the total assets if there is proper cooperation between the actors involved in all the concurrent proceedings. Proper cooperation implies the various insolvency practitioners and the courts involved cooperating closely, in particular by exchanging a sufficient amount of information. (..). Thus, the text does not refer to a group of companies' proceedings.

${ }^{21}$ Remarkably, there is nothing on "coordination" in these recitals.

${ }^{22}$ TRI-Leiden is currently working on a "protocols" project, see www.TRI-Leiden.eu.

${ }^{23}$ Adriaanse/Wuisman/Santen [1], p. 15.

${ }^{24}$ Kaplow [3].

${ }^{25}$ Davies [2].

${ }^{26}$ Whether the actual behaviour of an IOH was in compliance with that Principle can be assessed only ex post by a judicial or supervisory body.

${ }^{27}$ These resemble "rules" in Davies' [2] typology.

${ }^{28}$ Report of 12 December 2012, see http://ec.europa.eu/justice/civil/files/insolvency-regulation_en.pdf.

${ }^{29}$ The initial assignment was to draft Principles and Best Practices, but after an analysis of the text of (now) Recital 48 and the meaning of the concepts, TRI-Leiden suggested to INSOL Europe to change the wording of the assignment in Principles and Guidelines.
} 
and a model, which are subsequently applied on the analysis of regionally and globally established rules for IOHs. Report II contains an analysis based on the framework and model developed in report I, of the rules for IOHs in a number of European countries e.g. France, Germany, Italy, Latvia, Lithuania, the Netherlands, Poland, Romania, Serbia, Spain and the UK. The comparative analysis shows the differences in approach and solution on the various issues. I $n$ their turn, those differences indicate the room for Principles and Best Practices. Report III contains the draft Principles and Guidelines. ${ }^{30}$

The Statement of Principles and Guidelines for IOHs in Europe contains 7 Principles, 33 Guidelines and 83 Comments. Although it is explicitly non-binding of character and recognises that all national law and (professional) regulations have priority, it cannot be denied that its character may evolve in a "comply or explain" nature. After all, if there is supposedly a Principle or Guideline in the Statement that would have avoided certain damage that has occurred when administering the proceedings, a judge could easily question the $\mathrm{IOH}$ why (s)he has not followed the best practice as described in the Statement.

The Principles contain general standards for IOHs i.e. on the role of the law, regulations and the Statement itself (Principle 1); on professional (Principle 2) and ethical (Principle 3) conduct; on the administration of the estate (Principle 4); on communication (Principle 5); on coordination and cooperation (Principle 6); and on insolvency governance (Principle 7). Guidelines, sorted by Principle, and comments complete these and make them applicable in day-to-day $\mathrm{IOH}$ work. As an example, Principle 3 on ethics reads:

\section{An IOH performs with}

(a) integrity, meaning that an IOH is straightforward and honest;

(b) objectivity, including impartiality and independence, meaning that an $\mathrm{IOH}$ does not allow bias, conflict of interests or undue influence of others to override professional or business judgements and is solely guided by the interests of the estate;

(c) confidentiality, meaning that an IOH complies with the confidentiality of information acquired as a result of the appointment and avoids the abuse of confidential information.

As Comment 32 on the Statement notes, "serving as an IOH solely guided by the interests of the estate" is added since there should not be any other motive. "The interests of the estate" means primarily_but not only ${ }^{31}$ —all that would be helpful to secure or enlarge the estate. The Statement supports-not undisputedly-that an IOH in being "solely guided by the interests of the estate" should serve the benefits of the creditors as a whole and in doing so have regard to - in short—other stakeholder issues. ${ }^{32}$ This ethical principle is made more specific in Guideline 6.2:

\footnotetext{
${ }^{30}$ All reports can be retrieved from www.TRI-Leiden.eu.

${ }^{31}$ See for Dutch law regarding the importance to be given to the interests of the employees: HR, 24 February 1995, NJ 1996, 472 (Sigmacon II); HR 19 April 1996, NJ 1996, 727 (Saint Maclou). And regarding the interests of the insolvent person: HR 16 February 2015, ECLI:NL:HR:2015:87 (X/Van der Molen q.q.). ${ }^{32}$ Comment 32 refers to Article 172 UK Companies Act concerning the meaning of the "have regard to" phrase.
} 


\begin{abstract}
Best practice 6.2
When assets will be sold an IOH cooperates to the maximum extent possible with other IOHs as well as with all parties involved, in order to obtain the maximum aggregate value for the assets of the insolvent debtor as a whole, across legal entities and across national borders. If this cooperation would turn out to be detrimental to a specific estate, the concerned estate(s) will be offered full compensation for the consequences of cooperation from the other estates that are better off by the cooperation.
\end{abstract}

This Guideline 6.4 shows how the INSOL Europe (draft) IOH Statement attempts to make more abstract provisions of Article 31(3) EIR and Article 41(2.c) EIR Recast relevant and applicable in practice.

All Principles, Guidelines and Comments of the IOH Statement are focused on improving the effectivity and efficiency of insolvency proceedings. In short, they require an $\mathrm{IOH}$ to behave diligently, with courtesy and consideration towards all parties involved; to behave with integrity, objectivity and confidentiality, solely guided by the interests of the estate; to coordinate their actions and to cooperate to the maximum extent possible with each other and with courts involved in the insolvency proceedings, in order to (a) promote the orderly, effective, efficient, and timely administration of the proceedings; (b) provide for timesaving procedures to avoid unnecessary court proceedings or unnecessary costs; and (c) secure and enlarge the collectivity of assets.

Up to this Statement, IOHs did not have a specific set of rules of their own. ${ }^{33}$ The Statement was presented at the annual congress of INSOL Europe in Istanbul (Turkey) in October 2014 and was apparently well received. However, INSOL Europe did not decide to "adopt" 34 these rules as required by Recital 48 of the EIR Recast, since it felt they did lack support of their members. Another reason may have been the rather detailed and not completely parallel dealing with coordination in group of companies proceedings in the EIR Recast as published by the end of 2014. Anyway, all that remains of the project for now is the draft Statement, to be found on the website of INSOL Europe ${ }^{35}$ as well as on that of TRI-Leiden. ${ }^{36}$

\title{
4.2 The EU Cross-Border Insolvency Court-to-Court Cooperation Principles
}

In the same development, LLS - together with Nottingham Law School-received funds to draft Principles and Guidelines for Court-to-Court Cooperation. The project was co-funded by the Civil Justice Programme of the European Union and the International Insolvency Institute (III). The project's focus was to adapt the ALI and III report: "Transnational insolvency: Global principles for Cooperation in international Insolvency cases" (2012) to the European context and subsequently train European judges on the subject of judicial cooperation. The process of reworking the principles

\footnotetext{
${ }^{33}$ See, however: European Communication and Cooperation Guidelines for Cross-border Insolvency, developed under the aegis of the Academic Wing of INSOL Europe by Professor Bob Wessels and Professor Miguel Virgós July 2007.

${ }^{34}$ Whatever this might mean exactly.

35 www.insol-europe.org/download/resource/167.

36 www.TRI-Leiden.eu.
} 
was executed by Professor Bob Wessels in collaboration with experts representing around 25 different countries, especially a Review and Advisory Group of over 40 consultees (chaired by Professor Ian Fletcher), including some 25 judges, which has been consulted five times over a period of two years, and a Members' Consultative Group, formed by III Members. The project was terminated with the publication of the Principles on the project website by the end of December 2014 and the execution of three training sessions in the last months of that year. ${ }^{37}$

Here again, as in the IOH-project, the Principles have the overriding objective of enabling courts and insolvency practitioners to operate effectively and efficiently in international insolvency cases with the goals of maximising the value of the debtor's global assets, preserving where appropriate the debtor's business, and furthering the just administration of the proceeding (Principle 3.1). This principle is subsequently elaborated in 26 Principles in all. Determination of the language of the proceedings is one of them (Principle 14) and during the training session ${ }^{38}$ it appeared to be an important one since judges ascertained that knowledge of English in courts except where English is the mother tongue, is generally insufficient. Other Principles, e.g. Principle 5 (Case Management), 6 (Equality of Arms), 7 (Decision and Reasoned Explanation), 8 (Stay or Moratorium), 13 (Court Access), 16 (Communications between Courts), 18 (Notice to Creditors), 19 (Coordination), 20 (Notice to Insolvency Practitioners), 21 (Cross-border sales), all aim to contribute to this overriding objective of efficient and effective dealing in insolvency proceedings.

Importantly, Principle 16 ("Communications between Courts") attempts to have communication between courts, as it provides: "16.1. Courts before which insolvency cases are pending should, if necessary, communicate with each other directly or through the insolvency practitioners to promote the orderly, effective, efficient and timely administration of the cases. 16.2. Such communications should utilise modern methods of communication, including electronic communications as well as written documents delivered in traditional ways."

Moreover, Principle 13 ("Court Access") provides for the "main IOH" to have direct access to any court in any other Member State necessary for the exercise of its legal rights.

\subsection{The EU Cross-Border Insolvency Court-to-Court Communication Guidelines}

These Guidelines, 18 in all, are based on Principle $16.3^{39}$ that states: "For such (i.e. Communications between Courts) communications the EU JudgeCo Cross-Border Insolvency Court-to-Court Communication Guidelines should be employed." These Guidelines, to be considered as a sequel to the Principles dealt with in paragraph 4.2. of this paper, prescribe in detail how the communication as prescribed in the Principles should be executed. According to Guideline 2 ("Consistency with Procedural

\footnotetext{
${ }^{37}$ http://www.tri-leiden.eu/uploads/files/EU_Cross-Border_Insolvency_Court-to-Court_Cooperation_ Principles.pdf.

${ }^{38}$ Of over 60 judges from 16 countries.

${ }^{39}$ See also Guideline 1.2.
} 
Law") "[e]xcept in circumstances of urgency, prior to a communication with another court, the court should be satisfied that such a communication is consistent with all applicable Rules of Procedure in its state." In Guidelines 3.2 and 4.2 it is stated that when communicating between courts, or between a court and an $\mathrm{IOH}$, a court should, in advance, obtain the consent of all parties affected by these communications before disclosing the information. Moreover, the Guidelines contain e.g. detailed Guidelines on Methods of communication (Guideline 7), on E-communication (Guideline 8 and 9) and on Joint-Hearings (Guideline 10), mostly inspired by USA- and Canadian practice in e.g. the Nortel Case. ${ }^{40}$

Both the IOH Statement, the EU JudgeCo Principles and the EU JudgeCo Guidelines reflect a non-binding statement and therefore add to the volume of "soft law" in the area of international insolvency law. Although there is no organisation yet that has adopted these principles, they will probably play a role in future cases, as the ALI Principles and Guidelines already do in common law countries. ${ }^{41}$

\section{Conclusion}

The new version of the EIR, the EIR Recast, introduces the "communication, coordination and cooperation" concepts almost 20 times more than the present EIR. This is a major change. Not only lawyers of the $27 \mathrm{EU}$ members ${ }^{42}$ have to comply with these provisions, but courts will have to cooperate from $2017^{43}$ as well, not only amongst themselves but also with IOHs. Experience from the training sessions in the EU JudgeCo project shows that both professional groups, lawyers and judges, urgently need procedures and training on how to comply with these new rules. The Leiden Law School (LLS) projects described above, which intend to improve and clarify

\footnotetext{
${ }^{40}$ For example: On May 12, 2015, the Ontario Superior Court of Justice (Commercial List) and the United States Bankruptcy Court released consistent decisions requiring the allocation of assets from the sale of Nortel's businesses and intellectual property be based on a pro rata approach.(...) A joint hearing of the US and Canadian courts is scheduled for June 25, 2015 to determine some points of clarification following the decisions of the Ontario Superior Court of Justice (Commercial List) and the U.S. Bankruptcy Court dated May 12, 2015. See: http://www.kmlaw.ca/nortelnetworkscorporation. Also: blog Bob Wessels "2014-05-doc8 Nortel Network Joint hearing as a test case for EU JudgeCo Principle 10?."

${ }^{41}$ The ALI-III Global Principles and Global Guidelines are not just non-binding soft law. A strong signal of the practical use and guidance has been given by the Supreme Court of The United Kingdom (Conjoined Appeals in (1) Rubin \& Anor v Eurofinance SA \& Ors and (2) New Cap Reinsurance Corp Ltd \& Anor v Grant and others) [2012] UKSC 46 (24), that supported its arguments that "the modern approach [...] which is that the jurisdiction with international competence is that of the country of the centre of main interests of the debtor (an expression not without its own difficulties)" by referring to the 2012 Global Principles report. The Global Principles also contribute to the development of American law. The United States Court of Appeals for the Third Circuit (in Re ABC Learning Centres) on 23 August 2013 made references to Global Principle 1, and cites that "the overriding objective [is to] enable courts and insolvency administrators to operate effectively and efficiently in international insolvency cases with the goals of maximising the value of the debtor's global assets, preserving where appropriate the debtors' business, and furthering the just administration of the proceeding". Another part of the Global Principles report is cited too: " $\mathrm{t}]$ he emphasis must be on ensuring that the insolvency administrator, appointed in that proceeding, is accorded every possible assistance to take control of all assets of the debtor that are located in other jurisdictions. Id. at cmt. to Global Principle 24." See: Wessels/Boon/Kluwer [5].

${ }^{42}$ Excluded Denmark.

${ }^{43}$ The EIR Recast comes into force on 26 June 2017 (Article 92, as published).
} 
communication, coordination and cooperation between IOHs (the IOH-project) as well as between courts and courts and IOHs (the JudgeCo project), offer examples of sets of soft law, which will likely be of importance to actually execute the provisions of the EIR Recast.

Open Access This article is distributed under the terms of the Creative Commons Attribution 4.0 International License (http://creativecommons.org/licenses/by/4.0/), which permits unrestricted use, distribution, and reproduction in any medium, provided you give appropriate credit to the original author(s) and the source, provide a link to the Creative Commons license, and indicate if changes were made.

\section{References}

1. Adriaanse, J.A.A., Wuisman, I.S., Santen, B.P.A.: European Principles and Best Practices for Insolvency Office Holders. Report II: A Comparative Analysis of Rules for Insolvency Office Holders in Eleven European Countries as a Means to Identify Room for Principles and Best Practices, A Project Commissioned by INSOL Europe, Draft 30 April 2014. Available at: http://www.tri-leiden.eu/ uploads/files/IOH_Project_-_Report_II.pdf

2. Davies, P.L.: Introduction to Company Law, 2nd edn. Oxford University Press, London (2010)

3. Kaplow, L.: Rules versus standards an economic analysis. Duke Law J. 42, 557-629 (1992)

4. Wessels, B.: International Insolvency Law, vol. X, 3rd edn. Kluwer Academic, Norwell (2012)

5. Wessels, B., Boon, G.-J., Kluwer, W. (eds.): Cross-border insolvency law, international instruments and commentary (2015) (forthcoming) 